\title{
A novel Thermothelomyces heterothallicus PA2S4T fungus isolated from the soil induces chitinase production using orange peel flour
}

\author{
Um novo fungo Thermothelomyces heterothallicus PA2S4T isolado do solo induz produção de \\ quitinase utilizando farinha da casca de laranja
V. Pommer'; P. D. H. Rother²; L. M. Rasbold ${ }^{2}$; J. L. da C. Silva²; A. Maller²; R. de C. G. Simão²; M. K. Kadowaki ${ }^{2}$
${ }^{I}$ Centro de Ciências Biológicas e da Saúdel Laboratório de Bioquímica de Microrganismos, Universidade Estadual do Oeste do Paraná, 85819-110, Cascavel-PR, Brasil
${ }^{2}$ Centro de Ciências Médicas e Farmacêuticas/Laboratório de Bioquímica de Microrganismos, Universidade Estadual do Oeste do Paraná, 85819-110, Cascavel-PR, Brasil \\ *vipommer@hotmail.com \\ (Received on March 25, 2021; accepted on September 20, 2021)
}

\begin{abstract}
Chitinases are enzymes capable of hydrolysing the $\beta-1,4$ bonds of chitin releasing chitooligosaccharides and $\mathrm{N}$-acetylglucosamine and are widely used in food, pharmaceutical, and agricultural industries. Microorganisms are potential producers of this enzyme; however, there are no reports in the literature on the production of chitinase by fungi of the genus Thermothelomyces. Thus, this work aimed to investigate the production of extracellular chitinase using alternative carbon sources by the fungus isolated from soil, Thermothelomyces heterothallicus PA2S4T. The fungus was cultivated in a liquid medium supplemented with carbon sources and incubated at $40^{\circ} \mathrm{C}$ under stationary conditions for seven days. Orange peel flour was the best inducer for extracellular chitinase, with $82.3 \mathrm{U} / \mathrm{mL}$ of enzymatic activity. The highest production of chitinase was obtained on the tenth day, and the optimum $\mathrm{pH}$ and temperature for enzyme activity were 4.5 and $50^{\circ} \mathrm{C}$, respectively. Therefore, the fungus $T$. heterothallicus PA2S4T proved to be promising in the production of extracellular chitinase, which presents $\mathrm{pH}$ and temperature characteristics favourable to biotechnological application.
\end{abstract}

Keywords: thermophilic fungi, agro-industrial waste, enzyme.

Quitinases são enzimas capazes de hidrolisar as ligações $\beta-1,4$ de quitina liberando quitooligossacarídeos e N-acetilglicosamina, e muito utilizadas na indústria alimentícia, farmacêutica e agrícola. Os microrganismos são potenciais produtores dessa enzima, entretanto não há relatos na literatura sobre a produção de quitinase por fungos do gênero Thermothelomyces. Assim, este trabalho teve como objetivo investigar a produção da quitinase extracelular utilizando fontes alternativas de carbono pelo fungo isolado do solo Thermothelomyces heterothallicus PA2S4T. O fungo foi cultivado em meio líquido suplementado com fontes de carbono e incubado a $40^{\circ} \mathrm{C}$ em condições estacionárias por 7 dias. A farinha da casca de laranja foi o melhor indutor para quitinase extracelular com $82,3 \mathrm{U} / \mathrm{mL}$ de atividade enzimática. A maior produção da quitinase foi obtida no décimo dia, sendo o $\mathrm{pH}$ e temperatura ótimos de atividade da enzima foram 4,5 e $50^{\circ} \mathrm{C}$, respectivamente. Além disso, sua atividade se manteve estável entre $40-50{ }^{\circ} \mathrm{C}$ e na faixa de $\mathrm{pH}$ de 4.0-5.0. Portanto, o fungo T. heterothallicus PA2S4T demonstrou ser promissor na produção de quitinase extracelular, a qual apresenta características de $\mathrm{pH}$ e temperatura favoráveis à aplicação biotecnológica.

Palavras-chave: fungo termófilo, resíduo agroindustrial, enzima.

\section{INTRODUCTION}

Industrial biotechnology uses a variety of microbial enzymes composed mainly of amylases, proteases, pectinases, xylanases, lipases, and cellulases. In recent years, chitinases (EC 3.2.1.14) have gained prominence in this scenario because these enzymes are responsible for hydrolysing chitin, a linear polysaccharide composed of $\beta-1,4 \mathrm{~N}$-Acetylglucosamine (GlcNAc) found abundantly in nature, especially in arthropod exoskeletons and fungal cell walls [1-3].

Chitinases are classified based on their mode of action into endochitinases (EC 3.2.1.14) and exochitinases. Endochitinases are responsible for randomly hydrolysing the $\beta-1,4$ internal bonds 
of the chitin polymer, releasing chitooligosaccharides of lower molecular weights, such as chitobioses, chitotrioses, chitotetraoses, while exochitinase or $\beta$-N-acetylglucosaminidases (EC 3.2.1.52) cleave the products generated by the action of endochitinases and chitobiases releasing the monomers N-Acetylglucosamine (GlcNAc) [1, 4]. Fungal chitinases are grouped into the GH18 family based on the amino acid sequence of the enzyme, where its basic structure is composed of five domains: catalytic domain, chitin-binding domain, serine/threonine rich region, $\mathrm{N}$-terminal region, and C-terminal region [5]. In addition, the molecular mass of these enzymes range from 30 to $200 \mathrm{kDa}$, and the isoelectric point in the range from 3 to $8[4,6]$.

Despite advances in studies on the structure and mechanism of action of chitinases, there is little availability of these enzymes on the market for use in various biotechnological processes [7]. In agriculture, chitinases are used in biological control against fungi and insects, as an indicator of fungal activity in the soil [1]. In the pharmaceutical industry, the enzyme is added to antifungal creams or combined with drugs for the treatment of fungal diseases [1,3]. Chitin or chitosan hydrolysates, chitooligosaccharides, are also widely used in the medical sector, such as chitohexaosis and chitoheptaosis, which exhibit antitumor activities, and glucosamine, which is commonly used in the treatment of arthritis [1,3]. Chitooligosaccharides are still classified as prebiotics and these are added to foods such as yogurt, milk, juice, and tofu [3].

Fungi usually produce chitinases to infect other microorganisms, defend against other pathogens, and also in the process of cell differentiation $[3,4,6]$. Among the microorganisms, filamentous fungi can secrete a wide variety of enzymes, and consequently facilitate their growth in the environment [8]. Among the chitinase-producing mesophilic fungi are Trichoderma, Penicillium, Mucor, Aspergillus, and Metharhizium [4]. Thermophilic fungi, which grow in temperatures ranging between $40^{\circ} \mathrm{C}$ and $80^{\circ} \mathrm{C}$, comprise the fungi belonging to the order Sordariales, Eurotiales and Mucorales [9]. In the order Sordariales only thermophilic fungi of the family Chaetomiaceae are members, including Myceliophthora heterothallica, whose taxonomy was reclassified in a new genus called Thermothelomyces heterothallicus, reported as a producer of xylanase and cellulase enzymes [10-12]. However, there are no reports in the literature on chitinase production by this microorganism.

In addition, the use of agricultural by-products/agro-industrial residues as a supplement in bioprocesses for the production of fungal enzymes contributes to the use of low-cost carbon sources and avoids environmental problems due to inadequate disposal. Thus, this study aimed to investigate the production of extracellular chitinase using alternative carbon sources by the fungus isolated from soil, Thermothelomyces heterothallicus PA2S4T.

\section{MATERIALS AND METHODS}

\subsection{Isolation and strain identification}

The fungus was isolated from soil samples collected in the region of Nova Aurora, Parana state, Brazil, which is located at $24^{\circ} 30^{\prime} 9^{\prime \prime} \mathrm{S} 53^{\circ} 15^{\prime} 18^{\prime \prime} \mathrm{W}$. Taxonomic identification was performed by analysing products amplified with primers for ribosomal genes using the methodology described by White et al. (1990) [13]. The isolation of the genomic DNA of this fungus occurred from the mycelial mass obtained from a two-day liquid culture supplemented with $1 \%$ glucose. The fungus mycelium was collected by centrifugation $(5.000 \times \mathrm{g}, 10 \mathrm{~min})$, and the pellet was used for DNA extraction using the hexadecyltrimethylammonium bromide (CTAB) method [14]. Primers ITS1 and ITS4 were used to amplify the regions of ITS1, ITS2 and 5.8S. The polymerase chain reaction (PCR) mixture included $0.6 \mu \mathrm{M}$ of each primer, $0.2 \mathrm{mM}$ deoxynucleotides, $1.5 \mathrm{mM} \mathrm{MgCl} 2,5 \mathrm{x}$ green GoTaq ${ }^{\circledR}$ Flexi buffer (Promega), and $2.5 \mathrm{U}$ of GoTaq ${ }^{\circledR}$ Flexi DNA polymerase (Promega). The conditions of the PCR cycles consisted of an initial denaturation step at $95{ }^{\circ} \mathrm{C}$ for 2 minutes, 35 cycles at $94{ }^{\circ} \mathrm{C}$ for 45 seconds, $50{ }^{\circ} \mathrm{C}$ for 45 seconds and $72^{\circ} \mathrm{C}$ for 45 seconds, followed by a final phase extension at $72^{\circ} \mathrm{C}$ for 5 minutes. The PCR products were analysed on 1.0\% Tris-acetate-EDTA agarose gels (1.0\% agarose, 0.04 $\mathrm{M}$ Tris-acetate, and $1 \mathrm{mM}$ Na-EDTA), developed with ethidium bromide, and viewed under UV lighting. The determined sequences (ITS1, ITS2, and 5.8S) were then compared with other 
sequences deposited in the database of the National Biotechnology Information Center (NCBI) using the basic local alignment tool.

\subsection{Maintenance of the fungus}

The routine maintenance of the fungal strain in the laboratory was carried out in test tubes containing $5 \mathrm{ml}$ of potato dextrose agar (PDA), incubated at $40^{\circ} \mathrm{C}$ for seven days, and then kept in the refrigerator for a maximum period of 30 days.

\subsection{Cultivation conditions}

The fungus T. heterothallicus PA2S4T was grown in a Czapek liquid medium supplemented with $1 \%$ alternative carbon sources (sugarcane bagasse, sorghum bagasse, lemon peel, pear peel, tilapia fish scale, cicada exuvia, orange peel flour, apple flour, passion fruit fibre, and corn straw). Then $1.0 \mathrm{~mL}$ of the spore suspension $\left(2 \times 10^{5}\right.$ spores $\left./ \mathrm{mL}\right)$ was inoculated in sterile distilled water in Erlenmeyer flasks $(125 \mathrm{~mL})$, containing $25 \mathrm{~mL}$ of liquid medium. The cultures were incubated at $40^{\circ} \mathrm{C}$ under stationary conditions for seven days. After growth, the cultures were filtered and the cell-free filtrates after dialysis were used to determine enzyme activity.

\subsection{Enzymatic determination}

Chitinase activity was determined through a mixture of $90 \mu 1$ of chitin substrate (SigmaAldrich), $0.2 \mathrm{mg} / \mathrm{ml}$ in a $50 \mathrm{mM}$ sodium acetate buffer, a pH of 6.0 , and $10 \mu \mathrm{l}$ of diluted enzyme extract when necessary and incubated at $40^{\circ} \mathrm{C}$ for 30 minutes. The reaction was stopped with the addition of $200 \mu \mathrm{l}$ of $0.4 \mathrm{M} \mathrm{Na}_{2} \mathrm{CO}_{3}$ solution and, the products were measured in a spectrophotometer at $410 \mathrm{~nm}$. The chitinase unit was defined as the amount of enzyme required to produce $1 \mu \mathrm{mol}$ of $\mathrm{p}$-nitrophenol per minute of reaction.

\subsection{Determination of proteins}

Extracellular proteins were measured using the Bradford method (1976) [15] and using bovine serum albumin (BSA) as a standard. The unit was defined as $\mathrm{mg}$ of protein per $\mathrm{ml}$.

\subsection{Influence of time on the production of extracellular chitinase}

Cultures containing the Czapek liquid medium were supplemented with $1 \%$ orange peel flour carbon source, inoculated with fungal spores, and incubated at $40^{\circ} \mathrm{C}$ for 12 days. Each day the cultures were filtered to obtain the crude extract to carry out enzymatic assays and protein determination.

\subsection{Optimum pH and temperature and chitinase stability}

The optimal chitinase temperature was determined by incubating the enzyme with the substrate $0.2 \mathrm{mg} / \mathrm{mL}(\mathrm{w} / \mathrm{v})$ dissolved in a McIlvaine buffer $(0.1 \mathrm{M}, \mathrm{pH} 4.5)$ at temperatures ranging from 35 to $70^{\circ} \mathrm{C}$ for 30 minutes. Thermal stability was carried out by incubating the enzyme at temperatures of $40,50,60$, and $70^{\circ} \mathrm{C}$ and then aliquots were withdrawn at $0,10,30,60,90$, and 120 minutes. The optimal $\mathrm{pH}$ of chitinase was determined using the McIlvaine $0.1 \mathrm{M}$ buffer in the $\mathrm{pH}$ range of 3.0 to 8.0. The $\mathrm{pH}$ stability was determined by incubating the enzyme in the McIlvaine buffer (pH 3.0 to 6.0) in an ice bath for 24 hours and the residual chitinase activity was measured. 


\subsection{Statistical analysis}

All the experiments were performed in triplicate, and the results were presented as mean \pm standard error. Significant differences between the means of enzymatic activities were determined by an analysis of variance (ANOVA) followed by the Tukey test at the 5\% level of significance $(\mathrm{p}<0.05)$.

\section{RESULTS AND DISCUSSION}

\subsection{Strain identification}

The identification of fungal isolate PA2S4T was performed by sequencing the products amplified with the primers ITS1 and ITS4. The 523bp sequence of the ITS regions of the ribosomal DNA showed 99\% similarity with the species Thermothelomyces heterothallicus (Klopotek) (van den Brink \& Samson, 2012). The sequence of the region from ITS1 to ITS4 of this fungus is deposited and available in the NCBI database by accession number MW204601.1 (Figure 1). The fungi belonging to the Chaetomiaceae family are of great interest due to their thermostable enzymes, and are commonly addressed in the literature in studies of biomass degradation and biofuel production [16].

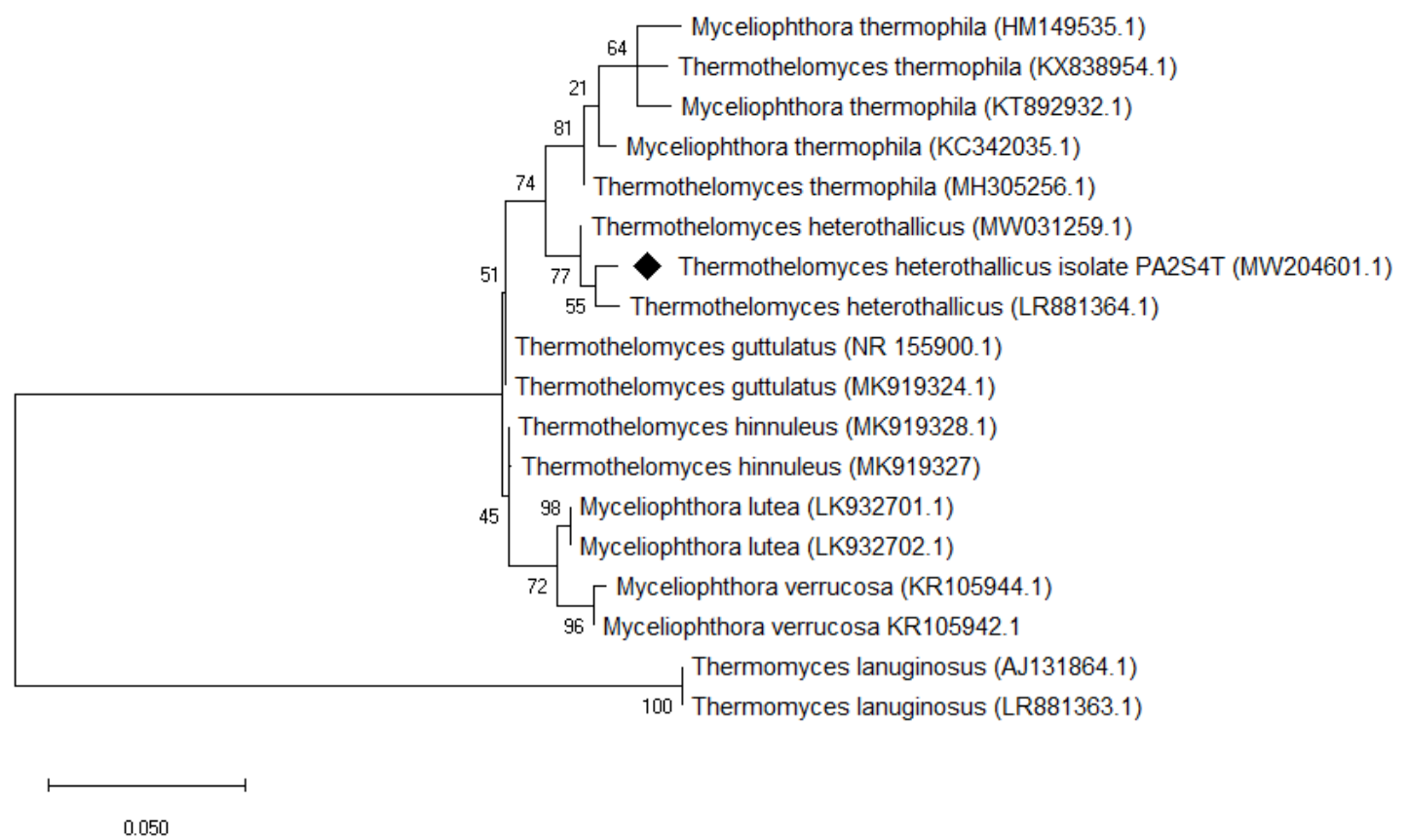

Figure 1 - A phylogenetic tree constructed from sequences of the ITS regions of the ribosomal DNA from Thermothelomyces heterothallicus PA2S4T and compared to sequences of other strains obtained from the NCBI GenBank database. The Thermomyces lanuginosus strain was used as an out-group. Fungus species are in bold symbols, followed by the Genbank accession number.

\subsection{Influence of carbon sources on chitinase production}

The production of extracellular chitinase by the fungus T. heterothallicus PA2S4T obtained from liquid cultivation showed that orange peel flour was the source of carbon that statistically showed the highest production of extracellular chitinase $(82.3 \mathrm{U} / \mathrm{mL})$, followed by lemon peel $(27.9 \mathrm{U} / \mathrm{mL})$. The chitinolytic activities considered statistically similar were obtained with corn straw, pear peel, and sugarcane bagasse, while lower chitinase induction values were observed with the carbon sources: apple flour, cicada exuvia, tilapia fish scale, sorghum bagasse, and 
passion fruit fibre (Figure 2). In general, the carbon sources used to induce chitinase production are compounds that contain chitin, such as waste from the fishing industry [16-18]. However, studies have shown the use of residues from orange to induce enzyme production, whether the bagasse or the peel of the fruit, such as in the production of pectinase and polygalacturonase by the saprophytic fungus Aspergillus fumigatus [19], the production of laccases by the fungus Peyronellaea pinodella [18], and pectinase production by the fungus Aspergillus niger [19]. This increase in the production of these enzymes may be related to the great presence of pectin $(42.5 \%)$ and soluble sugars, such as glucose, fructose, and sucrose (16.9\%), which together with cellulose $(9.21 \%)$ and hemicellulose $(10.5 \%)$ make up the orange peel, one of the main by-products generated by the citrus industry $[20,21]$.

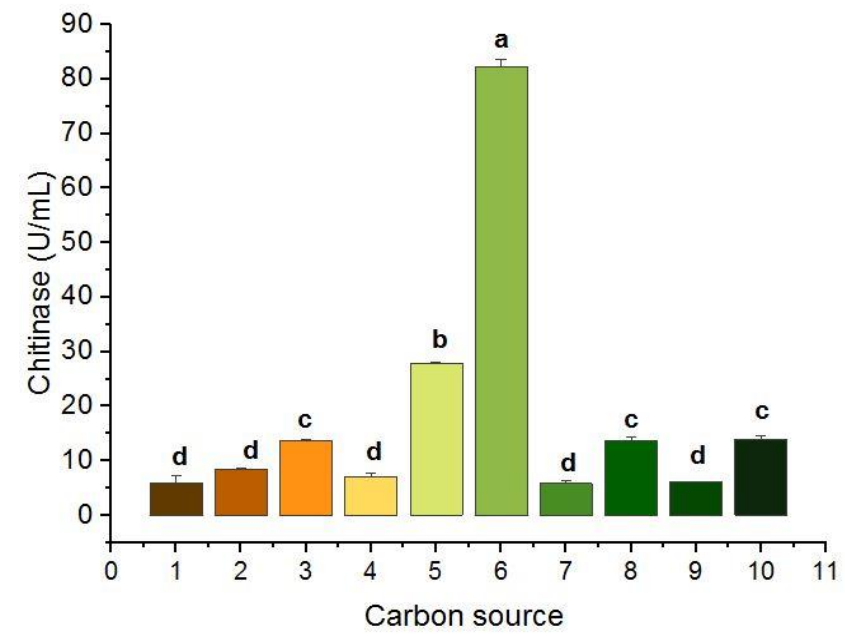

Figure 2 - Influences of carbon sources on chitinase production by the fungus Thermothelomyces heterothallicus PA2S4T. The liquid culture was supplemented with $1 \%(w / v)$ of different carbon sources and incubated under static conditions at $40^{\circ} \mathrm{C}$ for 7 days. The carbon sources are: apple flour (1), cicada exuvia (2), corn straw (3), tilapia fish scale (4), lemon peel (5), orange peel flour (6), passion fruit fibre (7), pear peel (8), sorghum bagasse (9) and sugarcane bagasse (10).

Table 1 shows the chitinases produced by different species of fungi and their sources of inducing carbons. Chitinases from thermophilic microorganisms are still lacking; there are only reports of Humicola grisea [22], Thermoascus aurantiacus var. levisporus [23], Chaetomium thermophilum [23], Myceliophthora thermophila C1 [24], and Thermomyces lanuginosus SSBP [6]. This study reports for the first time on the production of thermostable chitinases from the fungus Thermothelomyces heterothallicus. 
Table 1 - Chitinase production by fungi using different carbon sources.

\begin{tabular}{|c|c|c|c|}
\hline Fungus & Carbon source & Chitinase & Reference \\
\hline Alternaria alternata & Shrimp shells & $15.6^{\text {(c) }}$ & [25] \\
\hline Aspergillus niger LOCK 62 & Yeast Extract + Colloidal Chitin & $82^{(\mathrm{c}) *}$ & [26] \\
\hline Aspergillus terreus & Shrimp shell powder & $4.82^{\text {(a) }}$ & [27] \\
\hline Aspergillus terreus CBNRKR KF529976 & Fish scale & $3.7^{\text {(d) }}$ & [28] \\
\hline Beauveria bassiana & Colloidal chitin & $0.585^{(\mathrm{d})}$ & [29] \\
\hline Chaetomium thermophilum & Colloidal chitin & $2.32^{(\mathrm{d})}$ & [23] \\
\hline Humicola grisea & Chitin + colloidal chitin & $213.57^{(d)}$ & [22] \\
\hline Isaria fumosorosea & $\begin{array}{l}\mathrm{N} \text {-acetylglycosamine + colloidal } \\
\text { chitin }\end{array}$ & $284.09^{(\mathrm{d})}$ & {$[30]$} \\
\hline Metarhizium anisopliae IBCB 348 & Sugarcane bagasse & $12.44^{(b)}$ & [31] \\
\hline Metarhizium anisopliae IBCB 360 & Silkworm & $7.14^{\text {(b) }}$ & [32] \\
\hline Myceliophthora thermophila $\mathrm{C} 1$ & Glucose & $3.5^{\text {(a) }}$ & [24] \\
\hline Paecilomyces sp. & Colloidal chitin & $90^{\text {(c) }}$ & [33] \\
\hline Thermoascus aurantiacus var. levisporus & Colloidal chitin & $1.37^{(\mathrm{c})}$ & [23] \\
\hline Thermothelomyces heterothallicus $\mathrm{PA} 2 \mathrm{~S} 4 \mathrm{~T}$ & Orange peel flour & $82.3^{(\mathrm{c})}$ & [This study] \\
\hline Trichoderma asperellum UTP-16 & Starch & $2.05^{(b)}$ & [34] \\
\hline Trichoderma harzianum TUBF 966 & Colloidal chitin & $14.7^{(\mathrm{c})}$ & [35] \\
\hline Trichoderma viride & Colloidal chitin & $23.8^{(\mathrm{c})}$ & [36] \\
\hline Trichoderma viride AUMC 13021 & Colloidal chitin & $38.3^{\text {(a) }}$ & [37] \\
\hline
\end{tabular}

U/mg: (a); $\mathrm{Ug}^{-1}$ : (b); U/mL: (c); *nmol/h.

\subsection{Influence of time on chitinase production}

The maximum chitinase production was obtained on the 10th day and supplemented with orange peel flour as a carbon source in cultivation under stationary conditions (Figure 3 ). Rustiguel et al. (2012) (32) also reported that the maximum chitinase production of Metarhizium anisopliae using silkworm chrysalises occurred between the 8th and 12th days of culture.

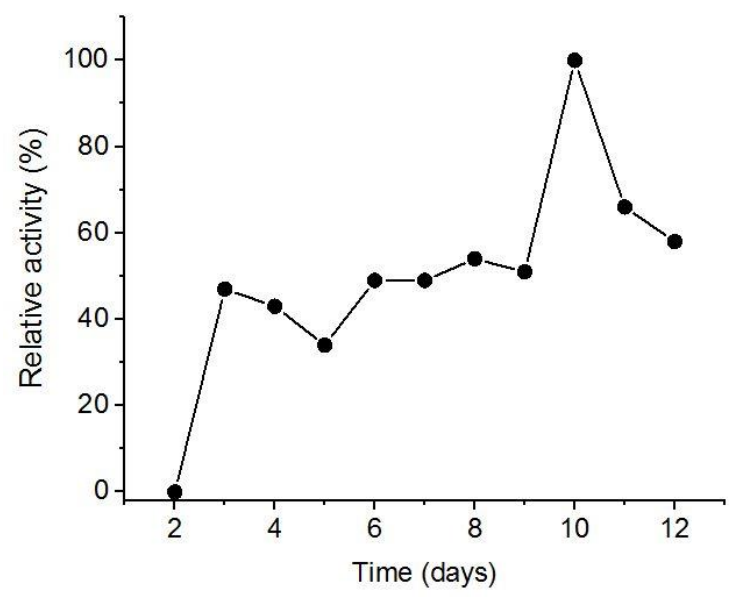

Figure 3 - Influence of time on chitinase production by the fungus Thermothelomyces heterothallicus PA2S4T in cultivation supplemented with orange peel flour, incubated at $40^{\circ} \mathrm{C}$ for 12 days under stationary conditions.

\subsection{Influence of temperature and pH on enzymatic activity and stability}

The temperature and optimal $\mathrm{pH}$ of chitinase activity of $T$. heterothallicus PA2S4T were $50^{\circ} \mathrm{C}$ (Figure 4A) and $\mathrm{pH} 4.5$ (Figure 4B), respectively. Similarly, the optimum temperature $\left(50^{\circ} \mathrm{C}\right.$ ) and the optimum $\mathrm{pH}$ in the range from 4.0 to 5.5 were observed for chitinase from M. anisopliae [32]. However, the $\mathrm{pH}$ values of $B$. bassiana chitinases were 5.5, 6.0, and 8.0 for the different isoforms 
of the enzyme produced by the fungus [38]. Chitinase from T. heterothallicus PA2S4T exhibited thermal stability at temperatures of 40 and $50^{\circ} \mathrm{C}$ during $120 \mathrm{~min}$; however, at temperatures of 60 and $70{ }^{\circ} \mathrm{C}$, there was a decrease in enzyme activity after $10 \mathrm{~min}$ of incubation (Figure 4C). The enzyme showed $\mathrm{pH}$ stability for $24 \mathrm{~h}$ at $\mathrm{pH} 4.0$ to 5.0, with $100 \%$ stable activity at $\mathrm{pH} 4.5$, as shown in Figure 4D. Rustiguel et al. (2012) [32] reported that chitinase from entomopathogenic fungus Metarhizium anisopliae exhibited thermostability at $50^{\circ} \mathrm{C}$ and $100 \%$ activity at pH 7 .
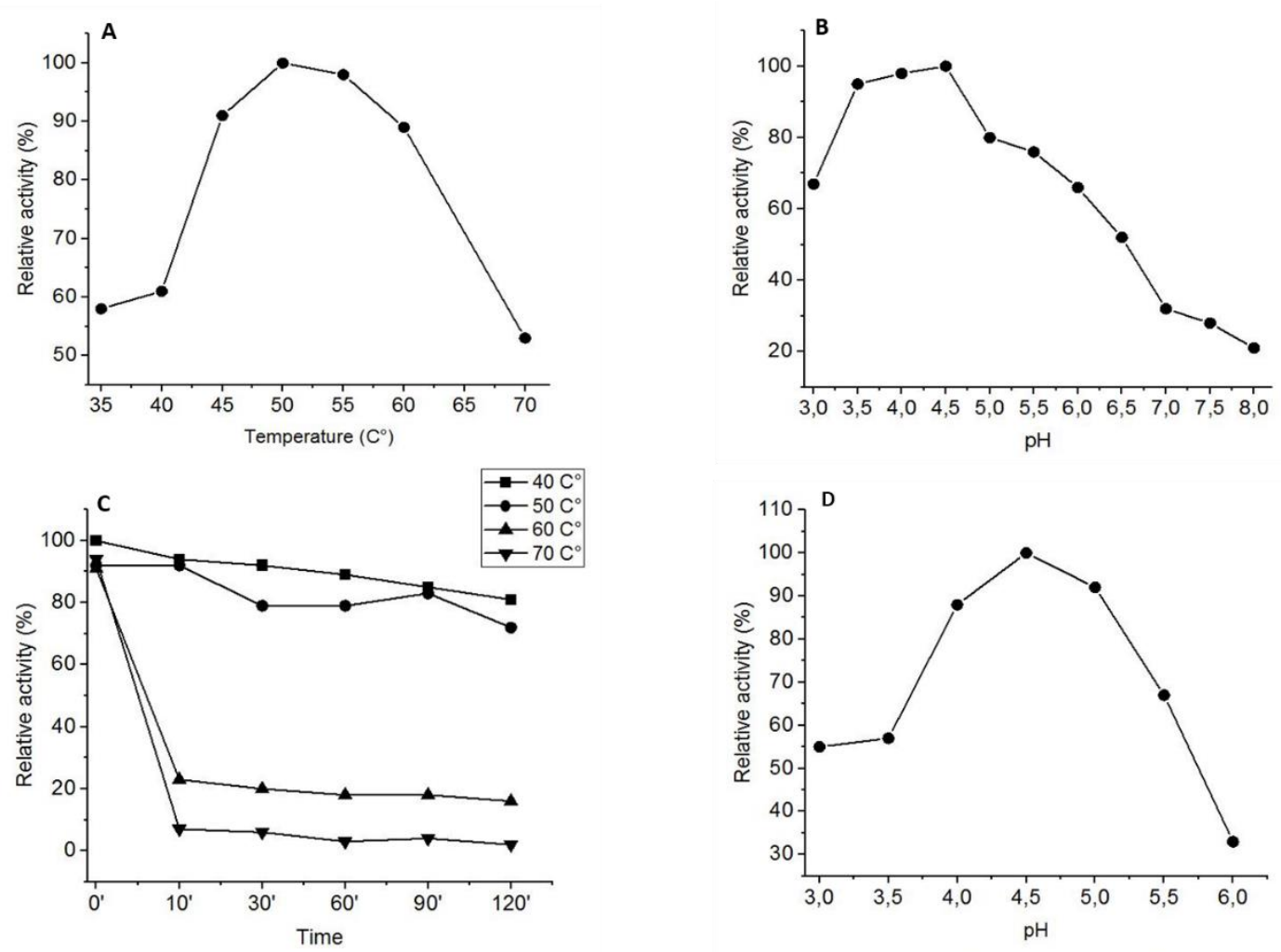

Figure 4 - Influence of temperature (A); Influence of $\mathrm{pH}(B)$; Thermal stability of chitinase $(C)$; on the chitinase activity incubated at different temperatures $40^{\circ} \mathrm{C}(\boldsymbol{\bullet}), 50^{\circ} \mathrm{C}(\bullet), 60^{\circ} \mathrm{C}(\mathbf{\Delta}), 70^{\circ} \mathrm{C}(\boldsymbol{\nabla})$ for up to

$120 \mathrm{~min}$; Stability at $\mathrm{pH}$ of chitinase of the fungus Thermothelomyces heterothallicus PA2S4T (D).

\section{CONCLUSION}

The thermophilic fungus Thermothelomyces heterothallicus PA2S4T isolated from the soil of western Parana state has great potential as a producer of extracellular chitinase using alternative carbon sources, mainly orange peel flour, which is a waste product of the orange juice industry. In addition, this is the first report on chitinase production by this fungal species using carbon sources with a chitin-free composition or its derivatives. The enzyme also exhibited optimal $\mathrm{pH}$ and temperature characteristics that provide biotechnological application and could be promising for the degradation of residues that contain chitins.

\section{ACKNOWLEDGEMENTS}

Paula D. H. Rother and Victoria Pommer are recipients of a fellowship from the Brazilian Federal Agency for Support and Evaluation of Graduate Education (CAPES) - Brazil and the National Council for Scientific and Technological Development (CNPq), respectively. 


\section{REFERENCES}

1. Hamid R, Khan MA, Ahmad M, Ahmad MM, Abdin MZ, Musarrat J, et al. Chitinases: An update. J Pharm Bioallied Sci. 2013;5(1):21-9. doi: 10.4103/0975-7406.106559

2. Jemli S, Ayadi-Zouari D, Hlima H Ben, Bejar S. Biocatalysts: Application and engineering for industrial purposes. Crit Rev Biotechnol. 2016;36(2):246-58. doi: 10.3109/07388551.2014.950550

3. Le B, Yang SH. Microbial chitinases: properties, current state and biotechnological applications. World J Microbiol Biotechnol. 2019;35(9):1-12. doi: 10.1007/s11274-019-2721-y

4. Karthik N, Akanksha K, Binod P, Pandey A. Production, purification and properties of fungal chitinases-A review. Indian J Exp Biol. 2014;52(11):1025-35

5. Khan FI, Bisetty K, Singh S, Permaul K, Hassan MI. Chitinase from Thermomyces lanuginosus SSBP and its biotechnological applications. Extremophiles. 2015;19(6):1055-66. doi: 10.1007/s00792-0150792-8

6. Khan FI, Govender A, Permaul K, Singh S, Bisetty K. Thermostable chitinase II from Thermomyces lanuginosus SSBP: Cloning, structure prediction and molecular dynamics simulations. J Theor Biol. 2015;374:107-14. doi: 10.1016/j.jtbi.2015.03.035

7. Stoykov YM, Pavlov AI, Krastanov AI. Chitinase biotechnology: Production, purification, and application. Eng Life Sci. 2015;15(1):30-8. doi: 10.1002/elsc.201400173

8. Sun X, Su X. Harnessing the knowledge of protein secretion for enhanced protein production in filamentous fungi. World J Microbiol Biotechnol. 2019;35(4):1-10. doi: 10.1007/s11274-019-2630-0

9. Morgenstern I, Powlowski J, Ishmael N, Darmond C, Marqueteau S, Moisan MC, et al. A molecular phylogeny of thermophilic fungi. Fungal Biol. 2012;116(4):489-502. doi: 10.1016/j.funbio.2012.01.010

10. Marin-Felix Y, Stchigel AM, Miller AN, Guarro J, Cano-Lira JF. A re-evaluation of the genus Myceliophthora (Sordariales, Ascomycota): Its segregation into four genera and description of Corynascus fumimontanus sp. nov. Mycologia. 2015;107(3):619-32. doi: 10.3852/14-228

11. Simões LCO, da Silva RR, Nascimento CEO, Boscolo M, Gomes E, da Silva R. Purification and Physicochemical Characterization of a Novel Thermostable Xylanase Secreted by the Fungus Myceliophthora heterothallica F.2.1.4. Appl Biochem Biotechnol. 2019;188(4):991-1008. doi: 10.1007/s12010-019-02973-8

12. de Oliveira TB, Rodrigues A. Ecology of Thermophilic Fungi. In: Tiquia-Arashiro S, Grube M, editors. Fungi in extreme environments: Ecological role and biotechnological significance [Internet]. Cham (CH): Springer; 2019. p. 39-57. doi: 10.1007/978-3-030-19030-9_3

13. White TJ, Bruns T, Lee S, Taylor J. Amplification and direct sequencing of fungal ribosomal Rna genes for phylogenetics. In: Innis MS, Gelfand DH, Sninsky JJ, White TJ, editors. PCR Protocols: a guide to methods and applications. San Diego (CA): Academic Press; 1990. p. 315-22. doi: 10.1016/b978-0-12372180-8.50042-1.

14. Góes-Neto A, Loguercio-Leite C, Guerrero RT. DNA extraction from frozen field-collected and dehydrated herbarium fungal basidiomata: performance of SDS and CTAB-based methods. Biotemas. 2005;18(2):19-32.

15. Bradford MM. A Rapid and sensitive method for the quantitation microgram quantities of protein utilizing the principle of protein-dye binding. Anal Biochem. 1976;72(1-2):248-54. doi: 10.1016/00032697(76)90527-3

16. Berka RM, Grigoriev IV, Otillar R, Salamov A, Grimwood J, Reid I, et al. Comparative genomic analysis of the thermophilic biomass-degrading fungi Myceliophthora thermophila and Thielavia terrestris. Nat Biotechnol. 2011;29(10):922-9. doi: 10.1038/nbt.1976

17. Phutela U, Dhuna V, Sandhu S, Chadha BS. Pectinase and polygalacturonase production by a thermophilic Aspergillus fumigatus isolated from decomposting orange peels. Brazilian J Microbiol. 2005;36(1):63-9. doi: 10.1590/S1517-83822005000100013

18. Patel RJ. Orange peel as an inducer for Laccase production in a novel fungal strain peyronellaea pinodella BL-3/4 and optimization of its cultural parameters by single parameter approach. Indian J Sci Technol. 2020;13(16):1656-67. doi: 10.17485/IJST/v13i16.296

19. Mrudula S, Anitharaj R. Pectinase production in solid state fermentation by Aspergillus niger using orange peel as substrate. Glob J Biotechnol Biochem. 2011;6(2):64-71

20. Rezzadori K, Benedetti S, Amante ER. Proposals for the residues recovery: Orange waste as raw material for new products. Food Bioprod Process. 2012;90(4):606-14. doi: 1016/j.fbp.2012.06.002

21. Ahmadi F, Zamiri MJ, Khorvash M, Banihashemi Z, Bayat AR. Chemical composition and protein enrichment of orange peels and sugar beet pulp after fermentation by two Trichoderma species. Iran J Vet Res. 2015;16(1):25-30. doi: 10.22099/ijvr.2015.2919 
22. Kumar M, Brar A, Vivekanand V, Pareek N. Process optimization, purification and characterization of a novel acidic, thermostable chitinase from Humicola grisea. Int J Biol Macromol. 2018; 116:931-8. doi: 10.1016/j.ijbiomac.2018.05.125

23. Li AN, Yu K, Liu HQ, Zhang J, Li H, Li DC. Two novel thermostable chitinase genes from thermophilic fungi: Cloning, expression and characterization. Bioresour Technol. 2010;101(14):5546-51. doi: 10.1016/j.biortech.2010.02.058

24. Krolicka M, Hinz SWA, Koetsier MJ, Joosten R, Eggink G, Van Den Broek LAM, et al. Chitinase Chi1 from Myceliophthora thermophila $\mathrm{C} 1$, a thermostable enzyme for chitin and chitosan depolymerization. J Agric Food Chem. 2018;66(7):1658-69. doi: 10.1021/acs.jafc.7b04032

25. Ghanem KM, Al-Fassi FA, Farsi RM. Statistical optimization of cultural conditions for chitinase production from shrimp shellfish waste by Alternaria alternata. African J Microbiol Res. 2011;5(13):1649-59. doi: 10.5897/AJB09.1937

26. Brzezinska MS, Jankiewicz U. Production of antifungal chitinase by Aspergillus niger LOCK 62 and its potential role in the biological control. Curr Microbiol. 2012;65(6):666-72. doi: 10.1007/s00284012-0208-2

27. Farag MA, Al-Nusarie ST. Production, optimization, characterization and antifungal activity of chitinase produced by Aspergillus terrus. African J Biotechnol. 2014;13(14):1567-78. doi: 10.5897/ajb2014.13628

28. Krishnaveni B, Ragunathan R. Chitinase production from marine wastes by Aspergillus terreus and its application in degradation studies. Int J Curr Microbiol Appl Sci. 2014;3(1):76-82

29. Elawati NE, Pujiyanto S, Kusdiyantini E. Production of extracellular chitinase Beauveria bassiana under submerged fermentation conditions. J Phys Conf Ser. 2018;1025(1). doi: 10.1088/1742$6596 / 1025 / 1 / 012074$

30. Ali S, Wu J, Huang Z, Ren SX. Production and regulation of extracellular chitinase from the entomopathogenic fungus Isaria fumosorosea. Biocontrol Sci Technol. 2010;20(7):723-38. doi: $10.1080 / 09583151003714091$

31. Aita BC, Spannemberg SS, Schmaltz S, Zabot GL, Tres M V., Kuhn RC, et al. Production of cell-wall degrading enzymes by solid-state fermentation using agroindustrial residues as substrates. J Environ Chem Eng. 2019;7(3):103193. doi: 10.1016/j.jece.2019.103193

32. Rustiguel CB, Jorge JA, Guimarães LHS. Optimization of the chitinase production by different Metarhizium anisopliae strains under solid-state fermentation with silkworm chrysalis as substrate using CCRD. Adv Microbiol. 2012;2(3):268-76. doi: 10.4236/aim.2012.23032

33. Homthong M, Kubera A, Srihuttagum M, Hongtrakul V. Isolation and characterization of chitinase from soil fungi, Paecilomyces sp. Agric Nat Resour. 2016;50(4):232-42. doi: 10.1016/j.anres.2015.09.005

34. Kumar DP, Singh RK, Anupama PD, Solanki MK, Kumar S, Srivastava AK, et al. Studies on exochitinase production from Trichoderma asperellum UTP-16 and its characterization. Indian J Microbiol. 2012;52(3):388-95. doi: 10.1007/s12088-011-0237-8

35. Sandhya C, Adapa LK, Nampoothiri KM, Binod P, Szakacs G, Pandey A. Extracellular chitinase production by Trichoderma harzianum in submerged fermentation. J Basic Microbiol. 2004;44(1):4958. doi: 10.1002/jobm.200310284

36. Sharaf EF, El-Sarrany AE-AQ, El-Deeb M. Biorecycling of shrimp shell by Trichoderma viride for production of antifungal chitinase. African J Microbiol Res. 2012;6(21):4538-45. doi: 10.5897/ajmr12.148

37. Abu-Tahon MA, Isaac GS. Anticancer and antifungal efficiencies of purified chitinase produced from Trichoderma viride under submerged fermentation. J Gen Appl Microbiol. 2020;66(1):32-40. doi: 10.2323/jgam.2019.04.006

38. Sassá DC, Varéa-Pereira G, Miyagui DT, Neves PMOJ, Wu JI, Sugahara VH, et al. Evaluation of kinetic parameters of chitinases produced by Beauveria bassiana (Bals.) Vuill. Semin Agrar. 2008;29(4):80714. doi: 10.5433/1679-0359.2008v29n4p807 